\title{
Discussion on the Innovational and Enterprising Talents Development of Local Universities in the Transformational Period
}

\author{
Wang Qingjun \\ School of Economy and Management \\ Shenyang Aerospace University \\ Shenyang, China
}

\author{
Xu Jiawang \\ School of Economy and Management \\ Shenyang Aerospace University \\ Shenyang, China
}

\begin{abstract}
The society is progressing, economy is developing and people's thoughts are changing. Local universities positively participate in the reform of education and teaching to change the thoughts and advance with times in the context that reform is growing vigorously in universities all round the nation. Besides, they take innovational and enterprising transformation as the focus point of modern education, which is not only inevitable trend of social development but also is conductive to future development for local universities.
\end{abstract}

Keywords-Local universities; Innovation \& Entrepreneurship; Development

\section{INTRODUCTION}

Innovational and enterprising education is the need of society and calling of times. higher education in the era of rapid social development and knowledge economy should not only focus on knowledge economy and academic education, but also should take innovation education and enterprise education as the focus which is required by the society and inevitable demand of today's rapid socioeconomic development.

\section{REALISTIC MEANING FOR INNOVATIONAL AND ENTERPRISING TALENT EDUCATION OF LOCAL \\ UNIVERSITIES IN THE TRANSFORMATIONAL PERIOD}

Innovational and enterprising education is a new talent training mode which is in accordance with the economic globalization as well as rapid development of the knowledge economy and is advanced education philosophy applicable to the promotion of education reform and higher education massification. Innovational and enterprising education for university students is a new education activity, aiming to cultivate their innovative awareness, pioneering accomplishment and ability to innovate. What's more, its proposal is to expand and deepen the value of enterprise education and shape as well as guide their thinking and behavior mode.

While facing the arrival of economic age, local universities should start to vigorously carry out deep research, fully play their distinctive advantages, positively dock with the government as well as the focus of regional economy. Besides, they have to positively promote the strategic principle of going global, strengthen the communication with public institution and set up platform for personnel transport. In real operation, they have to strengthen its efforts to optimize professional construction, innovative marketing applications, accelerate the transformation of scientific research, and promote local economic development.

\section{THE CURRENT CONDITION OF INNOVATIONAL AND ENTERPRISING EDUCATION FOR STUDENTS IN LOCAL UNIVERSITIES}

China's universities are affected by traditional ideas and traditional educational philosophy for a long time, the innovation and entrepreneurship education starts late and lags behind comparing to developed countries. Throughout the process of higher education reform, its proceedings wind down. Meanwhile, we start up late and relative educational philosophy as well as hardware is not perfect which to a large extent copy the mode of western countries and is not able to seek truth from facts and keep pace with times.

\section{A. Lagging behind ideas of innovation and entrepreneurship education}

Universities have long been constrained by traditions and they have a vague mind about innovation and entrepreneurship education. What's more, if they take it as the goal for students who have strong willing to start up their own business, it will lead to the lack of mission and responsibility. Besides, part education managers unilaterally connect it with employment rate with purely utilitarian purposes. Moreover, some students take it as a waste of education resources which leads to serious shortage of entrepreneurial incentives, and is not beneficial to arouse their innovation and entrepreneurship initiative.

Meanwhile, under the influence of social environment, innovation and entrepreneurship education is equipped with purely utilitarian purposes and some hold the idea that it will quickly bring along with economic benefits. And education managers believe that innovation and entrepreneurship activities belong to some students, and they ignore cultivation of innovative spirit \& innovative ideas and the improvement of comprehensive ability and formation as well as cultivation of occupational character. Therefore, various innovation contests become a mere formality and cannot achieve expected results.

\section{B. A lack of sufficient qualified teachers for innovation and entrepreneurship education}

Teachers, as a leader for students and guide for innovation and entrepreneurship education, their quality is 
related to the success or failure of innovation and entrepreneurship education. So, a powerful faculty team shall be the key to carry out successful education. However, at present, the situation is not optimistic. The innovation and entrepreneurship education in universities and overall faculty team quality is poor, lacking systematic entrepreneurial management knowledge as well as practical experience, diverse, multi-layer and systematic planning and requirement. While facing undertaking practice, their teaching contents are dull and lack guidance with low efficiency.

Even though in recent years, various universities have paid attention to the implementation of innovation and entrepreneurship education as well as the teacher quality, teachers' enthusiasm is not high because they are affected by academic title evaluation, Promotion appraisal and high job mobility. In terms of teaching model, most entrepreneurship teachers adopt traditional teaching model which is entrepreneurship single.

Besides, the number of teachers is not enough and their power is not strong. The entrepreneurship courses provided in most local universities are not equipped with professional teachers while other teachers take part-time job, who actually pay attention to their professional course teaching process as well as teaching reform and research. The number of faculty seriously restricts entrepreneurship course setting which can be only taken as selective courses which restrict the possibility and chance for students to learn innovation and entrepreneurship education

\section{Lagging behind university student entrepreneurship education model}

Education of local universities is affected by the educational reform in the new period which yet is restricted by traditional teaching model, namely the process from transferring knowledge to accepting knowledge. Besides, ideas with teacher, classroom and textbook as the core are dominant and in the whole teaching process, students are deemed as the objects of spreading and accepting knowledge and are responsible to maintain the absolute authority of teachers. What's more, teachers' traditional teaching ideas also affect the cultivation of creative awareness. A dazzling array of schools has not introduced innovation and entrepreneurship education into discipline construction planning, graduates-training target and quality evaluation system. While facing the entrepreneurship education in the new era, the main focus is paid attention to entrepreneurial competition, report and training which shall be difficult to realize students' value.

In university curriculum setting, the capital and location of entrepreneurship education are different from quality education and professional education, so the coordination between various institutions is hard to be realized in the whole course of promotion. In the teaching process, various factors shall create influence and schools are not able to deal with individual differences while taking traditional theoretical inculcation as the core without inspiring, exploring, and experiencing teaching methods. In addition, teachers depend on the textbook and lack flexible application and are not able to keep pace with local market economic development. Finally, it shall become a mere formality, losing realistic education meaning and talent cultivation meaning

\section{EXPLORATION ON THE PATH FOR LOCAL UNIVERSITIES TO POSITIVELY PROMOTE INNOVATION AND ENTREPRENEURSHIP EDUCATION}

University students especially local university students have unique merits in terms of entrepreneurship education. In the course of carrying out innovation and entrepreneurship education, local universities do not have superiority and their students are pragmatic. In the increasingly fierce social competition, local university students are longing for success with stronger desire to win. Meanwhile, in the new period of modern economic development, local governments are accelerating the pace of seeking opportunities for local economic development. So, comparing to local universities, they have geographical advantage to some extent. The whole nation is in the stream of social change while local government is speeding up the liberation of thought and reform. When facing increasingly fierce competition, they should give more support in terms of policies and encourage students to start up their own business in home village. Therefore, local universities should set up platforms to connect the economy and accelerate reform so as to encourage sky rocketing students to participate in innovation and entrepreneurship.

\section{A. Innovate ideas, positively respond to and try utmost to optimize internal and external environment for entrepreneurship}

In terms of society, the Government should actively guide the promotion. The cultivation of innovative awareness and ability cannot be limited to the university time but should be paid attention to by the whole society. From basic education, schools have to take the peopleorientation concept and arm creative students with innovative thoughts so as to cultivate them be equipped with creative thoughts since childhood. What's more, various sectors of the community should positively change their thoughts in terms of evaluating students and abandon the utilitarian standard philosophy but highlight their overall quality and comprehensive ability so as to provide healthy and harmonious social environment for students.

Ideology is the driving force of fostering innovational and enterprising talents in universities, and a good level of consciousness can better promote its reform. Besides, the starting point and the foothold for universities to elaborately promote the education reform should be students and only when they accept the concept of innovation and entrepreneurship, can they put it into practice which shall be the goal of reform so as to make education play its role. Local managers in colleges and universities should actively emancipate the mind, get rid of the shackles of traditional thoughts and concept so as to help students develop thinking and forge ahead to maximize their innovation and creativity in the premise of taking market as the orientation and having solid knowledge as well as professional skills. 


\section{B. Optimize structure and try unremitting efforts to promote the teaching reform}

Strengthen the cultivation and improvement of college students ' innovative consciousness and character, enhance the practice ability of innovation and entrepreneurship. Optimize the education model of local universities, innovative education curriculum system and translate the idea into real educational practice. All theories all ultimately rooted in the socio-economic environment and local universities should promote the combination of innovative education and practice and conduct reform on curricula, teaching methods and practice forms. What's more, local universities have to refer to the reality of local economic development so as to establish new innovative entrepreneurship which is in accordance with the local development.

Strengthen efforts to carry out entrepreneurship education, improve students ' ability in terms of expertise, management and comprehensive quality by setting various curriculum of enterprising education. In innovative and entrepreneurship education classrooms, local universities cannot adopt rigid education model but should create opportunities for practicing. In practice platform settings, they should not be confined to internal schools but should positively contract with enterprises to establish universityenterprise joint running modes so as to create bigger platform to carry out social practice and meanwhile encourage students to positively participate in and earnestly practice.

\section{Establish perfect teachers team}

The key of education development should be emphasis on teachers. Whether can universities be equipped with a teacher team with a high degree of specialization, comprehensive professional ability as well as good quality shall determine the progress and perfection of innovation entrepreneurship education. Comparing to key universities, a big demerit of local universities is the shortage of teacher resources. Besides, career guidance teachers are mostly those engaged in employment guidance in colleges and universities who lack entrepreneurial practice experience.

In terms of innovation and entrepreneurship guidance, local universities should increase investment and carry out training for existing teachers in terms of ideas, profession, practice, teaching styles and teaching modes etc. On the other hand, refer to successful experience of other universities to establish communication among universities and realize resource sharing. Meanwhile, local universities should vigorously attract external resources and recruit successful personnel to act as career guidance teachers and carry out guidance so as to strongly absorb the good business thinking and entrepreneurial ideas. The above three should be mutually implemented to continuously improve the teacher team construction of entrepreneurship.

\section{Perfect incentive mechanism and guarantee the continuity of entrepreneurship}

Managers of local universities should conduct in-depth investigation to constantly improve current rules and regulations while starting from the reality because thought is driven force while regulation shall be guarantee. In actual operation, they have to adopt flexible policies and measures. At present, more and more schools adopt credit system and students can create practice credit in terms of innovation and entrepreneurship. Concerning scholarship setting, the tradition one takes record as the core while an new method should be established based on the basic reform policy of innovation and entrepreneurship with relevant records so as to encourage more students participate in the entrepreneurship team. For those who enter society earlier with a strong entrepreneurship desire, universities can adopt flexible registration policy to fully implement the policy of student-orientation so as to encourage students to actively participate in the wave of innovation.

\section{CONCLUSION}

The Fifth Plenary meeting of the 17th CPC Central Committee set forth the opinion to take scientific progress as well as innovation as important support for accelerating the transformation of economic growth patterns which is also crucial strategic choice of twelfth five-year. The proposal of this strategic theory is of great significance for innovation and entrepreneurship education, which is also indispensible especially for universities. Besides, the practice of local university students' innovation and entrepreneurship is also important for the continuous development of university and society at large.

\section{REFERENCES}

[1] Wang Ming. On the cultivation of innovational and enterprising talents in local universities[J]. Journal of Hunan College of Financial and Economic, , 2010, 5th term:142-143.

[2] Yin Zhonghong. Brief analysis on the innovational and enterprising talents development of local universities in transition period[J]. Journal of Baicheng Normal College, 2014, 5th term.

[3] Li Sha. Innovative course setting and curriculum system applicable to local university transition development[J]. Journal of Chongqing University of Science and Technology: social science edition, 2014, 7th term: 147-149

[4] University student innovation and entrepreneurship education materials[M], Hou Wenhua Science Press, 2012, 35-38

[5] Wu Handong, Yu Yang, Guo Xuesong, Wang Lijie, Zha Enhui, Zhang Zhen. Study on the practical education system construction of university innovation and entrepreneurship education- Taking Food Science and Engineering of Liaoning Medical University as example [J]. Continuing Education,2015,05:49-50.

[6] Chen Peini, He Guiming, Zheng Qingzhong. Explore on the knowledge application management in General Education of Universities[J]. China Education Innovation Herald, 2008,16:34.

[7] Yang Jun. The application of Sina Weibo functions in university education and administration management $[\mathrm{J}]$. Data of Culture and Education,2015,03:64-65.

[8] Zhou Yanbo. Innovation Education in Universities [M], Science Press-2011:15-18.

[9] Education information construction and application of innovation in local universities [M], Zhang Deshi- Southeast University Press $-2011: 12-15$. 